"Mircea cel Batran" Naval Academy Scientific Bulletin, Volume XIX - 2016 - Issue 1

Published by "Mircea cel Batran" Naval Academy Press, Constanta, Romania /I The journal is indexed in:

PROQUEST / DOAJ / DRJI / JOURNAL INDEX / I2OR / SCIENCE LIBRARY INDEX / Google Scholar / Crossref /

Academic Keys / ROAD Open Access / OAJI / Academic Resources / Scientific Indexing Services / SCIPIO

\title{
THE SPECIFICITY OF COURT JUDGMENTS IN CASES APPEALED TO THE HCCJ WITH MILITARY FROM THE NAVY
}

\author{
Adrian-Constantin STOICA ${ }^{1}$ \\ Claudiu LAZAR \\ lonel BOSTAN ${ }^{3}$ \\ ${ }^{1}$ Professor PhD,"Ovidius" University Constanta, Faculty of Law \\ ${ }^{2} \mathrm{PhD}$, National Defense University "Carol I", Bucharest \\ ${ }^{3}$ Professor PhD,"Ștefan cel Mare" University, Faculty of Economics and Public Administration, Suceava
}

\begin{abstract}
This study focuses on a brief analysis on those court cases in the jurisdictional phase, dealt with by the administrative court, within the High Court of Cassation and Justice of Romania (HCCJ). Obviously, as already made evident by the topic of our paper, we have dealt with those cases involving military personnel - petty officers, warrant officers, officers of various ranks and positions - from the Romanian Navy. In the few pages at our disposal, we focused on the reasons for the actions in the respective courts, on the procedural framework, on the arguments used in appeals, on the motivation for maintaining a court decision, on the modification or cancellation of the judicial decisions appealed to the HCCJ.
\end{abstract}

Keywords: restructuring units/ military positions, military discharge, put at disposal, attributing costs/ damages.

\section{Introduction}

Our observations on the case laws under the circumscribed topic (Bostan, 2016) reveal that, within the service relationships of active military, be it warrant officers, petty officers or officers, it is difficult to exclude the possibility of disputes with financial implications. Besides, it is noteworthy, from the very beginning, that the decisions of various courts, as arranged on the time scale, taking into account the last six-seven years, reflect some turmoil of the personnel serving in the Navy, related to the material component of their lives. Not once, when dealing with situations where they felt aggrieved in their rights, active military have resorted to the judicial way. In these few pages at our disposal, we wish to analyze the reasons for the actions in the respective courts, the procedural framework, the arguments used in appeals, the motivation for maintaining a court decision, the modification or cancellation of the judicial decisions appealed to the HCCJ. In our opinion, the illustration of the solutions carefully selected from the judicial practice of the $\mathrm{HCCJ}$, in terms of the resolution of the appeals dealt with at this level - i.e. the Supreme Court/ Contentious Administrative and Fiscal Department - is likely to interest many readers, such as warrant officers, petty officers or officers or even civilians, situated entirely outside the issues in question, but whether or not jurists - want, out of curiosity, to learn about certain issues related to this interesting topic, suggested by its title.

Types of cases

Our approach takes into consideration those case related to contesting the legality of the military

DOI: 10.21279/1454-864X-16-I1-019

(c) 2015. This work is licensed under the Creative Commons Attribution-Noncommercial-Share Alike 4.0 License. discharge orders, setting wages, charging sums incurred by damage to the property of the MND (Ministry of National Defense) units. Issues such as those related to the establishment of the liability triggered by the recovery of various debits are quite common. Those lawsuits, reached under the jurisdiction of the High Court of Cassation and Justice $(\mathrm{HCCJ})$, refer mainly to: returns regarding pecuniary rights established contrary to the law, recover of the expenditure incurred by state for schooling warrant officers, petty officers or officers in military educational institutions, reunification of patrimony subsequent to the detection of losses in the inventory etc.

Analyzing the solutions generated by the deviations from the rules governing the relationships of Navy personnel. Case law elements

For the purpose of a concise assessment of the solutions generated by the deviations from the rules governing the relations of the military personnel, focused on the component that triggers pecuniary/financial consequences, referring to the usual practice of the HCCJ (www.legalis.ro) (dealing with the appeals against the decisions issued by Courts of Appeal), we consider it necessary to note briefly a few aspects.

Attributing the expenditure incurred by the state for schooling in military educational institutions In many cases, where the MND charges the expenditures incurred by the state for schooling warrant officers, petty officers or officers in military schools, when the latter ask to be discharged, by resignation, before the completion of the contract with the MND, we notice that the final decisions 


\begin{abstract}
"Mircea cel Batran" Naval Academy Scientific Bulletin, Volume XIX - 2016 - Issue 1
Published by "Mircea cel Batran" Naval Academy Press, Constanta, Romania /I The journal is indexed in: PROQUEST / DOAJ / DRJI / JOURNAL INDEX / I2OR / SCIENCE LIBRARY INDEX / Google Scholar / Crossref /

Academic Keys / ROAD Open Access / OAJI / Academic Resources / Scientific Indexing Services / SCIPIO
\end{abstract}

aim at maintaining the decisions of the courts of first instance, which often are "relentless" towards the debtor subjects. The legal basis taken into consideration is represented by the provisions of art. 41 of the Status of the military personnel (Romanian Parliament, 1995), providing that "in case of failure to respect the commitment, namely the time period provided for the military service, the persons concerned are required to repay the maintenance expenditures incurred during schooling, in proportion to the remaining unexecuted period". Almost constantly, the appellants' objections on the failure to prove the existence of the damage alleged by military units are considered unfounded; the evidence given in those cases, including expert accounting, is not likely to show that such debits would not have been determined in accordance with the legal provisions. It is noteworthy that, in order to strengthen the chances of recovering the costs of tuition, calculated according to the applicable legal framework, the files are consolidated with documents submitted by the military units where the appellants attended the courses, drawn up according to the methodology for establishing maintenance costs during schooling (Government of Romania, 1998). Also it is noted that the High Court considers that the objection regarding the inclusion in the damage calculation of the expenditures for the first year of study is unfounded. It is true (related to the legal framework prior to the peacetime suspension of conscription and the transition to the military service performed on a voluntary basis Romanian Parliament, 2005) that, according to art. 34 of Law no. 46/1996 on preparing the population for defense, "The young admitted to educational institutions, except those in military high schools, are considered incorporated", and, according to art. 35, "the military school students and the students who do not continue their education are sent to military units to complete the military service up to 12 months" (Romanian Parliament, 1996). Art. 66 of Law no. 46/1996 establishes the right to food, equipment, medicine, pay, military transport documents for conscripts, cadets and students of military educational institutions. However, the interpretation of these legal provisions - see the HCCJ Decision no. $5174 / 2012$ (HCCJ, 2012) - reveals that the legal texts mentioned above only establish a benefit in favor of the candidates admitted in an institution of higher education, without the need for prior military service satisfaction, the first year of study being assimilated to it. Regarding the expenditures related to the first year of military education, they represent the tuition expenditures that are not equivalent to the maintenance costs of a conscript, which are larger, incurred also by the provision of food, equipment, supplies, pay and transport. Then, if other subjects (debtors in the same field of schooling fees, who attended academic (military) courses, argue that, for certain compensation, the precedent set by the High Court - see HCCJ Decision no. 165/2011 (HCCJ, $2011)$ - is based on the wording: "(...) conscripts were those who served in the military, under by the Constitution, students - who were attending military colleges, schools of warrant officers and petty officers, and students - who were attending the courses of the Academy for Advanced Military Studies, the Military Technical Academy, the Military Medical Faculty etc. Through this distinctive list, the legislator showed that we cannot discuss about the same expenditures and about the same service amounts/values for the above listed categories of persons". The same decision, cited above, states that "the objection regarding the expenditures incurred for the equipment in the fifth year of study is unfounded, given that the students in the fifth year of study do not meet the tasks specific to the position of officer and do not enjoy the full rights due to an officer. At the end of the fourth year of study, the students of military educational institutions are advanced in the rank corresponding to the one of lieutenant, but they do not hold a military function, being still enrolled as students of the educational institution" (HCCJ, 2011). We want to demonstrate that, over time, by aiming at the exemption from liability regarding this kind of expenditures to which we referred here, it was also resorted to the notification of the Constitutional Court regarding the exception of unconstitutionality of art. 47 of GO no. 121/1998 on the material liability of the military (Constitutional Court, 2004). The content of the legal provision is as follows: "When soldiers are discharged or retired, when the military employees' contract terminates or when the civilian staff is no longer employed in military units, the military units which registered debts of final charges, regardless of their value, transmit them for execution to the financial authorities in the areas where the debtors reside. Confirmation of these bodies of receipt of the writ of execution is the act under which the claim is deducted from the accounts of the unit that had sent the enforcement order" (Government of Romania, 1998). The exception was raised by a debtor in this area, namely in an administrative case, claiming the annulment of imputation decisions (Court of Appeal), showing that "it discriminates between certain categories of citizens or military 


\section{"Mircea cel Batran" Naval Academy Scientific Bulletin, Volume XIX - 2016 - Issue 1 \\ Published by "Mircea cel Batran" Naval Academy Press, Constanta, Romania /I The journal is indexed in: PROQUEST / DOAJ / DRJI / JOURNAL INDEX / I2OR / SCIENCE LIBRARY INDEX / Google Scholar / Crossref / \\ Academic Keys / ROAD Open Access / OAJI / Academic Resources / Scientific Indexing Services / SCIPIO}

discharged or retired personnel, military employees whose contract terminates and the civilian staff that is no longer employed in military units, on the one hand, and other citizen soldiers, on the other hand (...). This discrimination resides in the fact that the imputation decisions issued as far as the former are concerned, are enforceable titles, while those issued in case of the other military do not represent such titles". On this occasion, the Constitutional Court's examination, among other things, "undertook a systematic interpretation of GO no. 121/1998 and found that the author's allegations are unfounded, since they do not take account the provisions of art. 25, paragraph (2) of the ordinance, stating that, in all cases, "the imputation decision is issued by the master or head of the unit whose committee carried out the administrative research and shall be enforceable" reveals an important conclusion. Namely, that "From this perspective, it is obvious that the criticized text of the law does not establish any discrimination between the categories of citizens mentioned by the author of the exception. As such, art. 47 of GO no. $121 / 1998$ is in accordance with the provisions of art. 16, paragraphs (1) and (2) of the Constitution, republished", which triggers "the rejection of the unconstitutionality exception of art. 47 of GO no. $121 / 1998$ on the liability of the military, approved by Law no. 25/1999" (Government of Romania, 1998). However, it is noteworthy that, on 9 February 2016, the Plenum of the Constitutional Court held that the impugned provisions (in another reference to the Court, regarding the exception of unconstitutionality) - art. 43 of GO no. 121/1998, which reads: "In the event that, after exhausting these remedies, the persons liable to pay compensation under this Ordinance deemed to have been injured in a legitimate right can address the competent court according to the law" - are contrary to the constitutional provisions of art. 21, paragraph (4) ("Administrative special jurisdiction is optional and free") (Constitutional Court, 2016). It was considered that they would contravene the Constitution, since they condition the access to the court by requiring the observance of the jurisdictional administrative proceedings provided by art. 31-42 of GO no. 121/1998. As a result, the exception of unconstitutionality was upheld.

Active military considered prejudiced by the rejection of discharge, subsequent to the reduction in the position rank triggered by the amendment of the unit's organizational chart.

In another category of cases (HCCJ, 2010), there falls the request of a military (petty officer) vs. the defendants (i.e. the Staff of the Navy and the
Ministry of National Defense) to cancel the Order of the Chief of the Navy Staff, issued in 2008, and to pay for damages and for court costs. The respective order appointed him in a new position that envisaged the modification of duties and the reduction of salary rights (food, cash compensation shifted from Rule 4 to Rule 2). Among other things, the appellant disagreed on the change, arguing that he cannot hold the position of commander of school ship $M$. for medical reasons, being exempt from prolonged physical effort, respiratory hazards and temperature variations.

\section{Similarities with other HCCJ Decisions}

It is noteworthy that there is a significant number of common elements found in this HCCJ decision and in another series of such acts, all referring to cases involving military from the Navy [such as: Decision no. 2371/2010 - Administrative Litigation. Cancellation of the administrative act, Decision no. 2983/2009 - Administrative Litigation. Cancellation of the administrative act. Appeal; Decision no. 3479/2009 - Administrative Litigation; Decision no. 3142/2009 - Administrative Litigation. Cancellation of the administrative act] (www.legalis.ro). However, the most representative is the one which we are going to fully present in the following lines. Our remark in this regard is that the issued solutions usually aim at maintaining the solutions of the courts of first instance, which often reject the requests of debtor subjects.

Turning to the petty officer's request to cancel the Order of the Chief of the Navy Staff, issued in 2008, and to be paid both damages and court costs (HCCJ, 2010), we should take into account several aspects. Thus, the MND response reveals that, in the restructuring process of the army, the military unit where the respective petty officer was employed had received a new organization chart, which provided for the reduction in rank for the position held by the appellant. The appellant expressed his option of being discharged. Under art. 3 of Order no. M-169/2001, the appellant was assessed by the Selection Board of the Navy Staff, he was ranked and proposed for another position. Because he rejected the proposal, he was put at disposal for a period of three months, by the Order of the Chief of the Navy Staff. Subsequently, this period was prolonged for another 3 months. Since on 31 November 2008 this extension by three months (the legal maximum) was to expire, it was necessary to clarify his position, in the sense of determining his quality of active or discharged military; therefore, he was appointed into a position corresponding to his military qualifications. Under the 


\section{"Mircea cel Batran" Naval Academy Scientific Bulletin, Volume XIX - 2016 - Issue 1 \\ Published by "Mircea cel Batran" Naval Academy Press, Constanta, Romania /I The journal is indexed in: PROQUEST / DOAJ / DRJI / JOURNAL INDEX / I2OR / SCIENCE LIBRARY INDEX / Google Scholar / Crossref / \\ Academic Keys / ROAD Open Access / OAJI / Academic Resources / Scientific Indexing Services / SCIPIO}

circumstances, and given the express provisions of the law (Art. 6 of GO no. 7/1998), the applicant requested to be discharged. Until 31 August 2008, the procedure was carried out within the legal framework, the applicant having the opportunity to opt either for the appointment in one of the proposed positions, or to be discharged. However, after 31 August 2008, he considered that the MND had "adopted an abusive and unlawful attitude in relation to the appellant and to other military personnel in similar situations", as, at that moment, it ought to have discharged him under GO no. 7/1998 and not appoint him to another position. According to the court of first instance, the MND justified the issue of the order as follows: "upon the termination of the disposal period for the assignment to another position, the provisions of art. 26, paragraph (2) of the Order of the Minister of Defense no. M-63 of 04 April 2007 entered into force. Thus, the Chief of the Navy Staff could appoint the appellant into a position from the organizational chart equal in rank with the one held by him, without the assessment by the selection committee. Upon the delivery of the decision by the court of first instance, the contested order was no longer producing legal effects, since the appellant was discharged on 31 December 2009. However, the court of first instance held that the assessment of the order's lawfulness was necessary in order to evaluate the accessory complaint related to the payment of moral damages. Under the civil decision no. 40/CA of 19 January 2009, the Court of Appeal, Constanta, remained irrevocable by rejecting the appeal on 3 December 2009; it ordered the partial annulment of the Navy Staff Order no. M.M.$119 / 2008$, in respect of the applicant, and the MND was forced to issue the discharge order, under GO no. 7/1998" (HCCJ, 2010). The justification for rejecting the claim for moral damages implied the indication of the fact that the unlawfulness of the orders regarding the plaintiff's placement at disposal and appointment to the mentioned position cannot in itself underlie the award of compensation, requiring evidence reflecting the negative moral consequences suffered by the plaintiff... Analyzing the appeal in relation to the reasons mentioned, the Court deems it as unfounded, in part, in terms of the action regarding the appellant's obligation, in connection with the admission of the main action part aiming at the annulment of the contested order and payment of the court costs. In part, the court decision under appeal is unlawful because the court of first instance failed to rule on the request for payment of the court costs representing the lawyer's fee (...). Regarding the rejection of payment for moral damages, this solution is correct because, within this case, there were not met the conditions provided by art. 18, paragraph (3) of Law no. 554/2004 and the provisions of art. 998 of the Civil Code (...). As a result, the High Court approved the appeal against the civil sentence no. 58/CA of 17 February 2010 of the Court of Appeal, Constanta, and amended, in part, the court decision under appeal. The amendment is as follows: the defendants are required to pay to the applicant the court costs (the lawyer's fee) amounting to $1.000 \mathrm{RON}$, based on the receipt enclosed in the file of the main case, under art. 274, paragraph (1) of the Code of Civil Procedure. In addition to the court costs required in the appeal, representing the lawyer's fee, the Court orders the defendants to pay the court costs amounting to 600 RON to the appellant, assessed under art. 274, paragraph (3) of the Code of Civil Procedure, and the other provisions of the decision are maintained.

Recovering damage from a commanding officer of the Navy Staff Service Scheme, following an audit of the Court of Auditors

The cases where commanding military officers in national defense structures are held responsible for the production of financial unlawfulness are rare. However, we want to briefly address this situation, in order to reveal several legal and financial interesting elements, given that the resources managed within these structures have eminently a public nature, their regime being special in terms of legislation. For the purpose of this topic, we are going to present the case of a battalion commander of the Navy Staff and in the Service of the Army Staff of the MND ( $\mathrm{HCCJ}$, 2013) - as tertiary credit officer. He required, in contradiction with the MND (the defendant), by the Jurisdiction Commission of Imputation, the annulment of Decision no. 17/CJ/85/2010 of 8 April 2010, issued by the defendant. As far as the grounds for the request are concerned, the applicant argued that, by the control act of the Court of Auditors, from 18 September 2009, as a result of the financial audit on the account for the execution of the 2008 state budget at the MU..., illegal actions were committed, which incurred damage. The control act (which underlies the Decision no. 31 of 29 September 2009, issued by the Chamber of Auditors of Constanta County) recorded that the $\mathrm{MU}$... damaged the state budget with 57,985.73 RON, with delay penalties amounting to 24,401 RON. (It is noteworthy that, according to the control body, this amount did not represent income, therefore, it should not be retained at the entity level, but transferred to the state budget, under art. 75 of Law no. 500/2002). 


\section{"Mircea cel Batran" Naval Academy Scientific Bulletin, Volume XIX - 2016 - Issue 1 \\ Published by "Mircea cel Batran" Naval Academy Press, Constanta, Romania /I The journal is indexed in: PROQUEST / DOAJ / DRJI / JOURNAL INDEX / I2OR / SCIENCE LIBRARY INDEX / Google Scholar / Crossref / \\ Academic Keys / ROAD Open Access / OAJI / Academic Resources / Scientific Indexing Services / SCIPIO}

Upon the appeal, the applicant showed that the incomes were thus referred to in the revenue and expenses budget for 2006 - 2009, although, in previous years, it was not approved based on a project; the MU project existed only for 2008 and 2009, which, however, the main credit officer disregarded (...). Claiming that he had a legal basis to consider as the unit's revenue the receipts from rental activities other than those from the rental of garrison accommodation premises, the applicant relied on several legal provisions (MND, 2008). The court of first instance (Court of Appeal from Bucharest), by civil court decision, dismissed the action brought by the applicant as unfounded. For the purpose of this decision, the court of first instance held that (...) the applicant requested the appointment of a Commission of administrative research in the Navy Staff in order to establish the liability for the material damage of 24,401 RON representing delay penalties. The Commission found that, by ordering the payment of that sum by the applicant as credit officer and the performance of this operation from the revenues of the unit, by the chief accountant, triggered an unlawful expenditure (under the provisions of point 3, letter k) of the Instructions on the liability of the military and civilian employees of MND, approved by MND Order no. M/5/1999), affecting the unit's revenues. It was considered that the payment of 24,401 RON is a loss, the guilt belonging to the applicant, for the amount of $12,200.5$ RON (50\%) (given the Order of the Minister of National Defense no. M5/1999, for the implementation of the provisions of GO 121/1998, which, in art. 52, letter $\mathrm{m}$ ), states that one of the responsibilities incumbent upon a military unit commander is to observe the legal provisions regarding the effective use of funds) and to the accounting officer, for the amount of 12,200.5 RON (50\%). The following measures were proposed: the recovery of damages from the two persons and issuance of the imputation orders by chief of the financial - accounting department of the UM in Bucharest, the entry in the accounts of the MU... of the value of the damage in the amount of 24,401 RON and the execution of the relevant payment notification procedures to the liable persons... The court of first instance also held that the applicant contested the Decision of imputation, which was rejected by Resolution no. A/879/26 January 2010 of the Navy Staff, that, against the decision to reject the appeal, the applicant lodged a complaint with the Jurisdiction Commission of Imputations, and by an Administrative-judicial decision, this Commission within the MND dismissed the complaint. The
Court further found "that the applicant had ordered the transfer to the state budget of the amount of $57,985.73 \mathrm{RON}$, through the payment order no. 985/18 September 2009, thus also paying the delay penalties from the unit's revenues. However, the payment of penalties could not be imposed from the revenues of the military unit, given that the annual budget laws approve the budget revenue and expenditure, and, as far as expenditure is concerned, the amounts approved are not intended to delay penalties, penalties, fines ". It was noted that the applicant's allegations regarding the consideration of the revenue earned by renting military hostels as revenues of the military unit, referring to the situation of the revenue and expenditure budget from previous years (contrary to Law no. $500 / 2002$ ), are not arguments for the favorable resolution of the case. Incidentally, the Instructions no. M 95/2006 of the Minister of National Defense clearly state that these are revenues to the state budget, and the provisions of GD no. 253/2003, approving the establishment under the MND of the activities entirely financed from the unit's own revenues, are not applicable to such revenues (...). It was also retained that the auditing report - carried in this case - cannot be taken into consideration, since it relies only on the expert's assessments (...). The Court held that these revenues were not revenues of the military unit, but revenues which had to be transferred to the state budget and to which the provisions of GD 253/2003 and GD 567/2003, which relate solely to the revenues from the activities entirely financed from the units' own revenues, did not apply (...). In light of these considerations, the court of first instance held that there are met the conditions provided for by art. 6 of the MND Order no. 5/1999 for the appellant's material liability regarding the amount of $12,200.5 \mathrm{RON}$, and the administrative acts establishing such liability are legal. Going through all this, "Following the appeal exercised by the applicant in question, the High Court held that there are no illegality grounds which would trigger either the cancellation or the modification of the decision issued by the court of first instance (...). Considering that there is no need, in terms of the grounds of the appeal, to resume all the aspects regarding the facts, given the detailed analysis undertaken by the court of first instance; in this respect, the High Court, responding punctually to the appellant's objections, observes that, in this case, the ground of appeal provided for by art. 304, point 8 of the Code of Civil Procedure (referring to the situation when the court, by misconstruing the legal document before it, changed the nature or the 


\section{"Mircea cel Batran" Naval Academy Scientific Bulletin, Volume XIX - 2016 - Issue 1 \\ Published by "Mircea cel Batran" Naval Academy Press, Constanta, Romania /I The journal is indexed in: PROQUEST / DOAJ / DRJI / JOURNAL INDEX / I2OR / SCIENCE LIBRARY INDEX / Google Scholar / Crossref / \\ Academic Keys / ROAD Open Access / OAJI / Academic Resources / Scientific Indexing Services / SCIPIO}

clearly and evidently doubtless meaning thereof), to which the appellant made reference, is not incident. According to the High Court, the objections regarding the misapplication of the law are unfounded, under art. 304, point 9 of the Code of Civil Procedure, stating that the judge, by analyzing the legality and validity of the contested administrative jurisdictional act, conducted a correct interpretation of legal texts of Law no. $500 / 2002$ and GD no. 253/2003 and GD no. $567 / 2003$, based on the facts, and established the legal nature of the income amounting to 57,985.73 RON (i.e. they were not revenues of the military units, but revenues which had to be transferred to the state budget). Moreover, this categorization of revenues, based on the shown legal provisions, was achieved through a thorough and detailed analysis, the arguments presented, which the High Court also appreciates as legal and appropriate, demonstrating and justifying the removal of the accounting expertise carried in this case, based on an erroneous assessment of the appointed expert, in connection to the incident legal texts. Finally, the High Court considers that, under art. 6 of MND Order no. 175/1999, the cumulative meeting of the conditions provided for the establishment of the military's material liability, with special reference to the requirement of guilt, either intentionally or by mistake, was correctly retained...". Thus, demonstrating the validity and legality of the decision under appeal, the High Court dismissed the appeal in question as unfounded.

\section{CONCLUSIONS}

By the issues discussed within our approach, we wanted to present to the interested parties some elements drawn from the HCCJ case law, in order to make them understand the dispute resolution methods, with obvious financial implications, generated by the deviations from the rules governing the relations of the military. And this, no matter if those judgments of the High Court shall give justice to a topic or to another, regarding the service relationships taken into consideration, namely of the military personnel or of the employer - entity of the national defense system. Our references have targeted those cases focused on contesting the legality of discharge orders, wage-setting orders, attribution of sums due to the occurrence of damage to the property belonging to Navy units. Obviously, there are also other HCCJ interesting and wellgrounded decisions, which we have not mentioned. However, as the jurisprudence in question develops, we propose to deal with this topic at a larger scale, especially since we have noticed that issues such as those regarding the establishment of the material liability incurred by the recovery of various debits are quite common. Moreover, the legal actions, reached under the HCCJ jurisdiction, often refer to the recovery of pecuniary rights contrary to the law, the recovery of the expenditure incurred by the state by schooling in military educational institutions, the reunification of patrimony subsequent to the detection of losses in the inventory etc.

\section{ACKNOWLEDGEMENT}

The authors would like to express grateful thanks the anonymous reviewers for their encouraging and constructive comments.

\section{BIBLIOGRAPHY}

[1]. Ionel Bostan (2016), Litigii având implicații financiare ivite în derularea raporturilor de serviciu ale personalului militar, Editura Militară, București.

[2]. Parlamentul României (1995), Legea nr. 80 privind Statutul cadrelor militare, modificată şi completată (the Romanian Parliament, Law no. 80/1995 on the Statute of the military, amended), Details at: http://www.dreptonline.ro/legislatie/statutul_cadrelor_militare.php

[3]. Parlamentul României (2005), Legea $\bar{n} r .395$ privind suspendarea pe timp de pace a serviciului militar obligatoriu şi trecerea la serviciul militar pe bază de voluntariat (the Romanian Parliament, Law no. 395/2005 regarding the suspension of peacetime conscription and the transition to the military service on a voluntary basis), Details at: http://legislatie.just.ro/Public/DetaliiDocument/67092

[4]. Parlamentul României (2004), Legea nr. 554 a contenciosului administrative (the Romanian Parliament, Law no. 554 of Administrative Offences), Details at:

http://www.cdep.ro/pls/legis/legis_pck.htp_act?ida=53818

[5]. Parlamentul României (1996), Legea nr. 46 privind pregătirea populaţiei pentru apărare (the Romanian Parliament, Law no. 46/1996 on preparing the population for defense), Details at: http://www.cdep.ro/pls/legis/legis_pck.htp_act_text?idt=16885

[6]. Curtea Constituţională (2016), Comunicat privind admiterea excepției de neconstitutionalitate a dispozitiilor art. 43 din Ordonanța Guvernului nr. 121/1998 privind răspunderea materială a militarilor 


\begin{abstract}
"Mircea cel Batran" Naval Academy Scientific Bulletin, Volume XIX - 2016 - Issue 1
Published by "Mircea cel Batran" Naval Academy Press, Constanta, Romania // The journal is indexed in:

PROQUEST / DOAJ / DRJI / JOURNAL INDEX / I2OR / SCIENCE LIBRARY INDEX / Google Scholar / Crossref /

Academic Keys / ROAD Open Access / OAJI / Academic Resources / Scientific Indexing Services / SCIPIO
\end{abstract}

(Constitutional Court, Communication on the admission of the exception of unconstitutionality of provisions of art. 43 of Government Ordinance no. 121/1998 on the liability of the military), Details at:

http://juri.ro/ccr-neconstitutionalitate-in-og-nr-121-1998-privind-raspunderea-materiala-a-militarilor

[7]. Curtea Constituţională (2004), Decizia nr. 281 referitoare la respingerea excepţiei de neconstituţionalitate a prevederilor art. 47 din Ordonanţa Guvernului nr. 121/1998 privind răspunderea materială a militarilor, aprobată prin Legea nr. 25/1999 (Constitutional Court, Decision no. 281/2004 relating to the dismissal of the objection of unconstitutionality of art. 47 of the Government Ordinance no. 121/1998 on the liability of the military, approved by Law no. 25/1999), Details at:

http://www.cdep.ro/pls/legis/legis_pck.htp_act?ida=51324

[8]. ICCJ (2010), Decizia nr. 5174. Contencios administrativ. Anulare act administrativ. Pronunţată în şedinţă publică, la data de 23 noiembrie 2010 (HCCJ Decision no. 5174/2010. Administrative litigation. Cancellation of the administrative act. Delivered in open session, on 23 November 2010). Details at:

http://legeaz.net/spete-contencios-inalta-curte-iccj-2010/decizia-5174-2010

[9]. ICCJ (2013), Decizia nr. 4886. Contencios administrativ. Anulare act administrativ. Recurs (HCCJ Decision no. 4886/2013. Administrative litigation. Cancellation of the administrative act. Appeal), Details at: http://legeaz.net/spete-contencios-inalta-curte-iccj-2013/decizia-4886-2013

[10]. ICCJ (2010), Decizia nr. 2371. Contencios administrativ. Anulare act administrativ, Details at:

http://legeaz.net/spete-contencios-inalta-curte-iccj-2010/decizia-2371-2010

[11]. ICCJ (2009), Decizia nr. 2983. Contencios administrativ. Anulare act administrativ. Recurs, Details at: http://legeaz.net/spete-contencios-inalta-curte-iccj-2009/decizia-2983-2009

[12]. ICCJ (2009), Decizia nr. 3479. Contencios administrative (HCCJ, Decision No. 3479. Administrative Litigation), Details at: http://legeaz.net/spete-contencios-inalta-curte-iccj-2009/decizia-3479-2009

[13]. ICCJ (2009), Decizia nr. 3142. Contencios administrativ. Anulare act administrative (HCCJ, Decision No. 3142. Administrative Litigation. Cancellation of the administrative act), Details at:

http://legeaz.net/spete-contencios-inalta-curte-iccj-2009/decizia-3142-2009

[14]. Guvernul României (1998), Ordonanţa nr. 121 privind răspunderea materială a militarilor (The Government of Romania, Ordinance no. 121/1998 on the liability of the military), Details at:

http://www.cdep.ro/pls/legis/legis_pck.htp_act_text?idt=17286

[15]. Guvernul României (2003), Hotărârea nr. 253 privind aprobarea infiintarii pe langa Ministerul Apararii Nationale a unor activitati finantate integral din venituri proprii, M.Of. nr. 171 din 18 martie 2003 (The Government of Romania, Decision no. 253 approving the establishment at the Ministry of Defence of activities fully financed from its own funds, Official Gazette no. 171 of 18 March 2003).

[16]. Guvernul României (2003), Hotărârea nr. 567 privind aprobarea infiintarii pe langa Ministerul Apararii Nationale si unitatile din subordinea sa a unor activitati finantate integral din venituri proprii, M.Of. nr. 388 din 5 iunie 2003 (The Romanian Government, Decision no. 567 approving the establishment at the Ministry of National Defense and in its subordinated units of activities fully financed from their own funds, Official Gazette no. 388 of 5 June 2003).

[17]. MApN (2008), Ordinul ministrului apărării nr. 128/2008 pentru aprobarea Instrucţiunilor privind folosirea de către personalul armatei şi alţi beneficiari a fondului construit al Ministerului Apărării, destinat cazării, refacerii capacităţii de muncă şi activităţilor recreative şi sportive, M.Of. nr. 12 din 7 ianuarie 2009 (MND, the Minister's Order no. 128/2008 approving the Instructions on the use by the military personnel and other beneficiaries of the buildings of the MND, for accommodation, restoration of the work capacity and recreational and sports activities, Official Gazette no. 12 of January 7,2009 ).

[18]. MApN (2007), Ordinul ministrului apărării nr. 66 din 12 aprilie 2007 pentru aprobarea Metodologiei privind determinarea/stabilirea cheltuielilor de întreţinere pe timpul şcolarizării/instruirii (MND, Minister's Order no. 66 of 12 April 2007 approving the methodology for determining/setting the maintenance costs during schooling/training). 